\title{
CONSCIENTIOUS OBJECTION AND EQUALITY LAWS: WHY THE CONTENT OF THE CONSCIENCE MATTERS
}

\author{
(Accepted 26 February 2019)
}

\begin{abstract}
By enacting equality laws the liberal state decides the limits of liberal tolerance by relying on content-based rather than content-neutral considerations. Equality laws are not and cannot be neutral. They reflect a content-based moral decision about the importance and weight of the principle of equality vis-à-vis other rights or interests. This leads to the following conclusions: First, since equality laws in liberal democracies reflect moral-liberal values, conscientious objections to equality laws rely, almost by definition, on unjustly intolerant, antiliberal and morally repugnant values. Secondly, we should not shy away from explicitly relying on moral-liberal views when deciding whether it is justified to grant exemptions from equality laws. Thirdly, conscientious objections to equality laws should normally not be tolerated or accommodated by the state, because conscientious objections that rely on what is rightly perceived as unjustly intolerant, anti-liberal and morally repugnant values should not be tolerated in a tolerant-liberal democracy.
\end{abstract}

\section{INTRODUCTION}

In the UK, in cases of religious conscientious objection, including to anti-discrimination laws, courts consistently apply a neutral rhetoric which almost completely ignores the moral soundness or legitimacy of the relevant conscience. The courts almost always avoid making any normative judgment about the content of the relevant conscience. Instead, they decide the cases before them while relying mostly on content-neutral justifications.

\footnotetext{
* My thanks are due to Megan Davidson for her superb research assistance and thoughtful comments on previous drafts, to John Adenitire and an anonymous reviewer for their exceptionally challenging and helpful comments, and to Faiza Ahmed for her help in preparing the paper for publication. Research Fellowship at the Jean Monnet Research Centre, Trento University, Italy, allowed me to complete writing the paper in an ideal academic environment.
} 
Here it is argued that the state, through the judiciary, must take a moral stand in cases of conscientious objection and differentiate between two types of cases:

Type 1: claims for exemption or accommodation that are directly based on repugnant, unjustly intolerant, anti-liberal and ultimately illegitimate values.

Type 2: claims that are based on values that may be irrational or morally misguided but are not necessarily unjustly intolerant or morally illegitimate.

Normative evaluation of the content of the conscience provides a weighty reason (though not necessarily a conclusive one) for not tolerating Type 1 - and for tolerating Type 2, under certain conditions. Even though I will aim to briefly outline the differences between cases of Type 1 and cases of Types 2, this paper will only analyse and evaluate cases of Type 1 - and within the context of equality laws. ${ }^{1}$

The normative argument according to which the judiciary must take a moral rather than a neutral stand in cases of conscientious objection is complemented by a descriptive argument according to which the legislature often does take a moral stand when it enacts the law from which an exemption is sought. Alternatively, and in case of lack of explicit or coherent legislative intention, it is argued that equality laws will become meaningless, at least to some extent, if a moral stand is not taken while applying them. It will therefore be morally and legally inconsistent if the courts refuse to take moral stand when deciding whether to grant conscientious exemptions as a judicial remedy to those who object to the law for moral-conscientious reasons.

In the following it is also argued that (a) accommodating conscientious objections is almost always an expression of tolerance; (b) deciding whether to accommodate conscientious objections means deciding the limits of tolerance; and (c) the judicial decision about the limits of tolerance within the context of accommodating conscientious objection should be made by relying on content-based

\footnotetext{
${ }^{1}$ For an in-depth discussion of cases of type 2, see Yossi Nehushtan and Stella Coyle, 'The Difference between Illegitimate Conscience and Misguided Conscience: Equality Laws, Abortion Laws and Religious Symbols', (forthcoming) in John Adenitire, (ed.), Religious and Conscientious Exemptions in a Liberal State (Hart Publishing, Oxford [2019]).
} 
rather than content-neutral considerations - especially when the law itself reflects or relies on content-based considerations.

These arguments will be established by referring to recent UK cases involving religious claims to be exempted from equality laws, and more specifically - cases involving a refusal to sell a 'gay marriage' cake and a refusal to provide services to same-sex couples. The examples will focus on non-discrimination laws in the commercial context. Therefore, the sort of equality at issue is not equality with respect to government action, but equality with respect to decisions of private actors. The main arguments, however, are applicable, with necessary modifications, beyond the context of decisions of private actors in the commercial context, yet these broader implications will not be discussed here.

\section{ACCOMMODATING CONSCIENTIOUS OBJECTION AND THE LIMITS OF TOLERANCE}

The starting point of the discussion is the assertion, which will not be defended or explored in depth here, that accommodating conscientious objection, typically by granting conscientious exemptions from the application of the law or of administrative policies, is usually the outcome of tolerance. ${ }^{2}$

Here, tolerance is understood as refraining from harming the 'other' although the tolerant person has good reasons (in her opinion) to harm that 'other'. The tolerant person makes an adverse judgment about another person, the adverse judgment provides the tolerant person with reasons to harm the other, but the tolerant person restrains herself and avoids harming the other. These three elements of (a) adverse judgment, (b) reasons for causing harm and (c) restraint, differentiate the concept and the attitude of tolerance from concepts such as respect or acceptance. Here, and for the purpose of this paper, it will be assumed - without trying to justify the following assertions - that first, the term 'harm' should be interpreted in the broadest way possible so as to include any negative

\footnotetext{
${ }^{2}$ For a detailed argument according to which granting conscientious exemptions is normally an expression of tolerance, see Yossi Nehushtan 'What Are Conscientious Exemptions Really About?' Oxford Journal of Law and Religion 2(2) (2013): pp. 393-416. For a critical discussion of the argument that the principle of tolerance better explains the practice of granting conscientious exemptions, see John Adenitire, 'Conscientious Exemptions: From Toleration to Neutrality; From Neutrality to Respect' Oxford Journal of Law and Religion 6(2) (2017): pp. 268-292.
} 
behaviour towards another - and any limitations imposed on another's freedom; second, a person is harmed as long as her condition is worsened according to her own perspective; and thirdly, harm to others might also be caused by omission.

The principle of tolerance better explains both the practice of accommodating conscientious objection by granting conscientious exemptions and the attitude of those who grant the exemptions. Typically, granting conscientious exemptions from a legal rule presupposes that the state does not share the conscientious objector's values or their way of balancing between values, or believes it would be unbearable and indeed intolerable if everyone shared the objector's kind of conscience and reasoning. Otherwise, the exemption would have been the general rule rather than the exception to it.

When the state, for example, grants exemptions from equality laws to religious organisations, the state morally disapproves the religious conscience that prescribes discrimination against protected groups (most commonly - on the basis of sex, sexual orientation and religion). If the state perceived the religious discriminatory conscience or practice as morally desirable, it would not have enacted equality laws to begin with. Exemptions from equality laws are often granted only to religious organisations. This may lead to perceiving these exemptions as an expression of favouritism rather than tolerance. This perception is only partly true. Religious organisations do get special, positive treatment within the context of equality laws but the true meaning of this favouritism is that religious organisations are the only ones that are being tolerated by the state. This unique mixture of favouritism and tolerance does not contradict the argument that granting conscientious exemptions is almost always an expression of tolerance.

The same argument applies to cases in which the state exempts pacifists from compulsory enlistment to the army; religious groups from compulsory education laws; or physicians from performing abortions. If the state morally approved these types of conscience, it would not have enacted compulsory enlistment laws; compulsory education laws and permissive abortion laws.

The state usually makes an adverse judgment about the conscientious objector's values or their way of balancing between values. This judgment gives the state reasons not to grant the conscientious 
objector an exemption from a legal rule - or more generally - not to accommodate the objection, thereby harming the objector. If the state decides to grant conscientious exemptions after all, it can be seen as tolerant. The state may tolerate conscientious objections for pragmatic reasons - and that would be an expression of pragmatic tolerance; or for principled reasons - and that would be a case of principled tolerance where the state acknowledges the conscientious objector's right to be tolerated.

The argument that granting conscientious exemptions - or more generally - accommodating conscientious objection, is in most cases the outcome of tolerance, may be seen too broad. For the purpose of this article, however, there is no need to subscribe to this broad argument. A narrower argument can be suggested, according to which granting conscientious exemptions - or more generally accommodating conscientious objection, is almost always the outcome of tolerance in cases where the relevant general rule is not morally neutral, i.e. in cases where the general rule reflects a moral view. As will be argued below, this is always the case when the liberal state enacts equality laws.

One possible objection to the argument that granting exemptions from equality laws is almost always the outcome of tolerance is that in more than a few typical cases, the court or the legislature are struggling to determine the legitimate boundaries not of tolerance but of the scope of the law and the legitimate powers of the state. ${ }^{3}$ The law, for example, may prohibit landlords from refusing to let their property on the basis of race. The law may also decide that this rule does not apply when the property is a bedroom in one's small house. Alternatively, the court may decide to exempt landlords in these cases from the general non-discrimination rule, even in lack of statutory exemption. It can be argued that allowing home-owners to discriminate on the basis of race in that specific case is not an expression of tolerance but rather a recognition (that perhaps can coincide with perfectionist liberalism) that there are compelling reasons against enforcing the principle of equality in this case. The fact is, however, that in many cases determining the boundaries of the law and the powers of the state means determining the limits of tolerance as well. In the example above, the legislature and the court

\footnotetext{
${ }^{3}$ And I thank the anonymous reviewer for indicating that point and giving the example that follows.
} 
(or simply 'the state') make adverse judgment about racist landlords - if this is indeed a liberal state. This judgment gives the state reasons to apply the non-discrimination rule in all cases (therefore harming racist landlords). The liberal state also has reasons against applying the non-discrimination rule in some cases. In our case, the reason against applying the non-discrimination rule could be the right to privacy or the well-known liberal distinction between the public and the private sphere. If the state acts on these reasons by exempting landlords from the application of the law in defined cases, the state is in fact tolerant towards these landlords. This reasoning applies, so I argue, with regard to all laws that reflect and enforce moral views about the way people should behave.

Since the practice of granting conscientious exemptions from laws which reflect a moral view is an expression of tolerance, it is closely related to the complex question of the limits of tolerance. And if the state is generally a liberal state, the exact question will be that of the limits of liberal tolerance. There are various ways of not tolerating intolerant conscientious objectors - or any objectors to obeying laws that reflect moral views. The authorities may grant them an exemption but condemn their values or behaviour. The authorities may also grant them an exemption and, at the same time, deny them any governmental support or subsidy. In appropriate cases, the authorities can also refuse to grant an exemption. The state should always express an attitude of intolerance towards unjustly intolerant conscientious objectors. The exact nature of that attitude may vary.

The limits of tolerance towards conscientious objectors can be decided by applying one of two possible approaches: taking into account content-neutral considerations or taking into account content-based considerations. It is possible, of course, to apply both approaches, but a decision will have to be made as to which approach prevails or should be accorded more weight. If the legislature takes a liberal-moral stand when it enacts the law from which an exemption is claimed, then those who object to the law for conscientious reasons and whose conscience does not rely on intolerant and to a lesser extent - irrational values or beliefs, have a stronger case (other things being equal) to be granted conscientious exemptions. Those who base their conscientious claim on values that are unjustly intolerant or on utterly irrational beliefs have a much 
weaker case. The content of the conscience should be taken into account by the courts, along with other relevant considerations, if the liberal state, through its legislature, already decided to subscribe to substantive or perfectionist liberalism and to eliminate the availability of bad options, to discourage people from making bad choices and to not tolerate illiberal, unjustified intolerance.

Various kinds of moral disagreement (or other types of disagreement) should be tolerated by the state, whereas other kinds of disagreement should not. In order to distinguish the two, a valuebased examination of the conscience in question must be made. More specifically, when the states takes a moral-stand when it enacts its laws, the state should differentiate between two types of cases:

Type 1: claims for exemption or accommodation which are directly based on repugnant, unjustly intolerant, anti-liberal and ultimately illegitimate values. This type of cases will be discussed below within the context of conscientious objection to equality laws.

Type 2: claims which are based on values that may be irrational, intolerant or morally misguided but are not necessarily morally illegitimate. This type of cases, which will not be discussed here, includes, for example, refusal to perform abortion or to provide contraception; ${ }^{4}$ refusal to wear safety helmets; ${ }^{5}$ refusal to work on the religious day of rest ${ }^{6}$ refusal to receive or allow medical treatment (e.g. getting blood transfusion, as is the case regarding Jehovah Witnesses); ${ }^{7}$ refusal to compulsory military service; ${ }^{8}$ or even refusal to use the internet. ${ }^{9}$

This distinction can only be maintained if we subscribe to perfectionist liberalism and apply content-based considerations - while rejecting neutral liberalism and giving limited weight to neutral

\footnotetext{
${ }^{4}$ For an ECtHR's refusal to grant exemption to pharmacists who refused to sell contraception see Pichon and Sajous v. France Application 49853/99 (2 October 2001). The possible argument that the refusal to perform abortion in fact relies on anti-liberal, illegitimate values - and therefore falls within cases of type 1 - will not be discussed here.

${ }^{5}$ See generally, Sebastian Poulter, Ethnicity, Law and Human Rights (Oxford, 1998), ch. 8.

${ }^{6}$ Ruth Gavison and Nahshon Perez, 'Days of Rest in Multicultural Societies: Private, Public, Separate' in Theoretical and Historical Context (edited by Peter Cane, Carolyn Evans and Zoe Robinson; Cambridge University Press, 2008): pp. 186-213.

${ }^{7}$ R v. Blaue [1975] 1 W.L.R. 1411.

${ }^{8}$ Bayatyan v. Armenia (2012) 54 EHRR 15.

9 Blackburn \& Anor v. Revenue \& Customs [2013] UKFTT 525 (TC), (where two beekeepers had won the right not to file their VAT returns online after claiming that to do so was contrary to their religious belief).
} 
considerations. A brief account of these concepts will ground the conceptual framework of this paper.

Perfectionist theories hold that the state has a duty or at least a right to promote well-being or human flourishing by supporting and protecting certain values and ways of life. These theories demand the state to act - or to refrain from acting - in order to create and maintain legal and social conditions that best enable their subjects to pursue valuable and worthwhile lives, rather than any kind of life. ${ }^{10}$ Any perfectionist political or moral theory holds that some ideals of human flourishing are sound whereas others are not; that the state is justified in favouring sound ideals; and that there is no general moral principle that forbids the state from favouring sound values, as long as these values are indeed sound. Perfectionist liberalism normally holds that freedom and autonomy are distinct, sound values, ${ }^{11}$ and it defends and promotes the liberal perception of freedom and autonomy either because continuous autonomy and freedom are inherently valuable or because they are necessary instruments for living a valuable and worthwhile life.

Neutral liberalism, as understood for the purpose of this paper, requires the state to pay equal respect to competing moral claims and ways of life. It requires that the state should not endorse, promote or restrict any value or way of life, despite the fact that the state's authorities may believe that some values and ways of life are worth pursuing whereas others are not. According to any perception of neutral liberalism, when the state decides whether to restrict people's freedom - and in our case, the freedom to treat others differently - it should ignore the moral content of the values on which the claim for the 'freedom to discriminate' is based. The state can only take into account content-neutral considerations, such as (a) who will be harmed more - those who discriminate against others if they are not allowed to discriminate - or those who will be discriminated against if the discrimination against them is allowed; (b) whether there are alternative service providers; (c) is the service provider or the service itself public or private; (d) the sincerity of the values held by the discriminator; (e) whether the service is offered to the general public; (f) whether the service provider started the

\footnotetext{
${ }^{10}$ Steven Wall, Liberalism, Perfectionism and Restraint, (2007): p. 8.

${ }^{11}$ Joseph Raz, The Morality of Freedom, (1986): p. 19.
} 
business or joined the workplace before a new 'no-discrimination' duty was introduced; etc.

The distinction between perfectionist liberalism and neutral liberalism corresponds, therefore, with the distinction between contentbased and content-neutral considerations (and in this paper - as pertains to judicial decisions). It has been argued that the distinction between content-based and content-neutral considerations is ambiguous; that it has its limitations; that it is incorrectly applied by the courts; and that it lacks merit. ${ }^{12}$ Within the context of this paper, however, this distinction is both plausible and of great importance. When there is a clash between religious freedom and the principle of equality, and in a typical case - when a religious person seeks a permission to discriminate against others because of their sexual orientation or because of the religious person's views about gay people, a perfectionist-liberal would or should compare the relative weight of (a) the freedom to discriminate against others as a result of one's religious belief; and (b) the principle of equality. Within the narrower context of a refusal to provide a service to gay people (or to any other customer if the refusal relies on the homophobe's views about gay people) the perfectionist-liberal would ask whether acting on homophobic, religious views should be tolerated in a tolerantliberal democracy; Whether acting on these views is so morally repugnant to the extent that it denies legal protection from those who act on these views. A neutral-liberal, however, would reject this line of thought. The way in which neutral-liberalism is understood for the purpose of this paper prevents the courts from acting on any meaningful normative judgment (or any normative judgment at all) with regard to the legitimacy or moral soundness of the values that ground the behaviour of the homophobic, religious person. The only relevant considerations would be content-neutral ones, as described above. These considerations could be used in order to interpret the

\footnotetext{
${ }^{12}$ R. George Wright, 'Content-Based and Content-Neutral Regulation of Speech: The Limitations of a Common Distinction' University of Miami Law Review 60(3) (2006): pp. 333-364; Geoffrey Stone, 'Content Regulation and the First Amendment' William and Mary Law Review 25(2) (1983): pp. 189-252; Christopher Schultz, 'Therapeutic Jurisprudence: Content-Based Restrictions on Free Expression: Reevaluating the High Versus Low Value Speech Distinction (symposium)' Arizona Law Review 41 (1999) 573; Erwin Chemerinsky, 'Content Neutrality as a Central Problem of Freedom of Speech: Problems in the Supreme Court's Application' Southern California Law Review 74 (2000): pp. 49-64; Chemerinsky, 'The First Amendment: When the Government Must Make Content-Based Choices' Cleveland State Law Review 42 (1994): pp. 199-214; Marvin Ammori, 'Beyond Content Neutrality: Understanding ContentBased Promotion of Democratic Speech' Federal Communications Law Journals 61 (2009): pp. 273-324.
} 
law, i.e. to decide whether there was discrimination at all or whether the discrimination is proportionate and therefore allowed. These considerations can also be used to decide whether the discriminator should be exempt from the application of the equality law.

This paper is a specific implementation of a general argument that will not be defended here, according to which it would be a mistake to equate liberalism with what is called neutral liberalism - or with noninterference or not taking a stand. Such a perception of liberalism would justify the criticism levelled at liberalism, according to which liberalism is the opinion of those who have no opinion, or the behaviour of those who do not act in accordance with their values. ${ }^{13}$ Liberalism is first and foremost a theory that perceives autonomy, freedom and equality (as understood by liberalism itself) as goods. Since it is a truism that these goods cannot be protected and promoted by continuous non-interference, liberalism in fact requires the state to interfere and at times to restrict autonomy and freedom in order to secure continuing autonomy and worthwhile freedom. In order to do so, the state should sometimes give priority to content-based considerations over content-neutral considerations when it restricts rights and freedoms.

This paper derives from a substantive-liberal point of view which is fairly close to Raz's notion of perfectionist-liberalism. It relies on a rather radical perception of substantive-liberalism which is, in some aspects, more far-reaching than Raz's perfectionist-liberalism. By saying that I refer mainly to ways of protecting and promoting autonomy and morality which I may support and Raz may reject. ${ }^{14}$ More specifically, whereas Raz would argue that government may use means short of coercion to eliminate the availability of bad options, including ones that affect one's autonomy or simply cause 'moral harm', 15 I would suggest that coercion may be justifiable in some of these cases, and as long as its aim is to promote or protect autonomy or other liberal values and principles. I will not try to justify or elaborate the exact meaning of the perfectionist-liberal basis of this paper, at least not in a direct, systematic manner. I will simply argue that holding a radical perfectionist-liberal approach has

\footnotetext{
${ }^{13}$ For a similar view see Stanley Fish, There's No Such Thing as Free Speech - and it's a Good Thing Too (1994), pp. 134, 138.

${ }^{14}$ However, it can also be argued that Raz's perfectionism is actually more radical than the way in which Raz himself presents it: RP George, Making Men Moral (1993) ch. 6.

${ }^{15}$ Raz pp. $410-419$ n [11].
} 
a few important implications which are relevant to the topic of this paper - and that within the specific context of equality law - the suggested perfectionist-liberal approach is the only one that coincides with the purpose of equality laws in a liberal democracy.

\section{CONSCIENTIOUS OBJECTION, ILLEGITIMATE VALUES}

AND EQUALITY LAWS

\section{A. Introduction}

Here I discuss what I called 'cases of Type 1', i.e. cases in which the claim for exemption or accommodation is directly based on unjust, intolerant, anti-liberal and illegitimate values or practices. Such are, for example, homophobic or racist views and unjust discriminatory practices (e.g. a refusal to provide services to gay people; excluding women from the public or political sphere; discriminatory 'separate but equal' practices and so on). In this section I will focus on cases in which a claim for exemption or accommodation has being made in light of an equality law that prohibits discrimination on the ground of sexual orientation. ${ }^{16}$ Within this context, as well as within similar contexts, the argument about the illegitimacy of some views is a hybrid argument. It is both a normative argument and a descriptive one. It is normative as it assumes (without trying to justify this point here) that treating others unfavourably because of their identity (including sexual identity) is almost always morally repugnant. It is also a descriptive argument as far as the law, beyond the relevant equality law, reflects the above moral stand. This is indeed the case in the UK - and in many other democracies - with regard to sexual orientation. ${ }^{17}$ Within this context, four recent cases will be used as examples: Ashers Baking (refusal to sell a 'gay marriage' cake), ${ }^{18}$ Bull

\footnotetext{
${ }^{16}$ Even though highly relevant to the arguments presented here, I will not discuss the statutory exemption given to religious groups and organisations which allows them to discriminate on grounds of sexual orientation in the field of employment.

${ }^{17}$ Russell Sandberg, 'The Right to Discriminate' Ecclesiastical Law Journal 13(2) (2011): pp. 158-159, 157.

${ }^{18}$ Gareth Lee v. Ashers Baking [2015] NICty 2. The recent Supreme Court decision in this case will not be addressed here. Suffice it to say that that decision continued to apply the misguided practice of judicial content-neutral-reasoning. For the Supreme Court decision, see Lee v. Ashers Baking Company Ltd \& Ors (Northern Ireland) [2018] UKSC 49. For criticism of that decision and its reasoning, see Yossi Nehushtan and Stella Coyle, 'Ashers Baking (Part 1): The Supreme Court's Betrayal of Liberalism and Equality' UK Constitutional Law Association (5 Nov 2018), https://wp.me/p1cVqo-1BZ; Yossi Nehushtan and Stella Coyle, 'Ashers Baking (Part 2): Do Homophobes and Racists have a Right Not to Manifest Liberal Messages?' UK Constitutional Law Association (6 Nov 2018), https://wp.me/p1cVqo$1 \mathrm{C} 2$.
} 
(refusal to let a bed and breakfast room to a gay couple), ${ }^{19}$ Ladele (refusal to register a civil partnership between a gay couple), ${ }^{20}$ and McFarlane (refusal to counsel same sex couples on sexual matters). ${ }^{21}$

Notwithstanding important differences between these cases they all share one crucial point. In all four cases the refusal to provide a service relied on an adverse judgment that the conscientious objector made about gay people. In three of the four cases (Bull, Ladele and McFarlane) a service was denied to gay couples because they were gay. In the fourth case (Ashers Baking) a service was denied not because of the identity of the customer but because of his views (i.e. supporting gay marriage).

In order to prescribe the right response to cases of Type 1 within the context of equality laws, it is necessary to properly understand the purpose of equality laws. Specific purposes of equality laws may vary according to the legislature's intent - so far as a coherent intent can be found, the wording of the law - and the legal and social background. Yet within the commercial context most equality laws share, either explicitly or implicitly, a similar general purpose (or purposes). ${ }^{22}$ In the following I shall explore these purposes and evaluate their implications with regard to cases of Type 1 .

\section{B. The Purpose of Equality Laws: Broad or Narrow Purpose}

Within the context of providing services to the general public, equality laws may have either a broad or a narrow general purpose. The Ashers Baking case may help in distinguishing between the two. In Ashers Baking a service was denied not because of the identity of the customer but because of his views - supporting gay marriage. This is one of the reasons that makes Ashers Baking a difficult case for some. The argument here is that Ashers bakery's owners did not refuse to serve gay people (a gay person was even employed by the

\footnotetext{
${ }^{19}$ Bull and another v. Hall and another [2013] UKSC 73.

${ }^{20}$ Ladele v. London Borough of Islington [2009] EWCA (Civ) 1357.

${ }^{21}$ McFarlane v. Relate Avon [2010] EWCA Civ 88.

${ }^{22}$ For describing the general purposes of all anti-discrimination laws, see Tarunabh Khaitan, A Theory of Discrimination Law (OUP, Oxford, 2015). In short, Khaitan argues that these purposes are securing negative freedom; securing access to an adequate range of valuable opportunities; and securing selfrespect. These three goods are necessary, according to Khaitan, for promoting personal well-being (chapter 4). See also on page 121, where the purpose of discrimination law is described as reducing and ultimately removing 'any significant advantage gap between a protected group and its cogent groups'.
} 
bakery). ${ }^{23}$ They simply refused to bake a cake that conveyed a message that contradicted their deeply held values. Their deeply held values are that gay people are not equal to heterosexuals and as such should not be allowed to be married. Thus, a service was denied because the service provider held a negative view about gays as gays. This is why Ashers Baking is not that different from the other three cases mentioned above. It is indeed different in the non-important sense that the bakery's owners were willing to provide their baking services to gay people (as opposed to the case in Ladele, Bull and McFarlane). It is not different in the more important sense that a service was denied because the service provider believed that gay couples should not enjoy equal rights - and acted upon this belief while denying a service.

According to the common view, applying equality or anti-discrimination laws does not require inquiring into the motives or the reasons for the refusal to provide a certain service - or more generally, the motives for discrimination. ${ }^{24}$ This may be true in cases where the outcome of the refusal is discriminatory, even though there was no intention to discriminate. ${ }^{25}$ In such a case the purpose of the law is to eliminate the discriminatory outcome regardless of the reasons for the discriminatory behaviour and regardless of whether there was an intention to discriminate. It would be a mistake however to completely ignore the reasons for refusing to provide a service in all cases. We can think of two possible cases. In the first, the refusal to provide a service discriminates against customers on the basis of their protected characteristics. Here, the reasons for the refusal (i.e. whether the discriminatory act resulted from conscious decision, prejudice, antipathy, good faith, etc.) are normally irrelevant. In the second case, the refusal to provide a service does not result from the costumer's protected characteristics. Rather, it relies on discriminatory values that lead the service provider to make an adverse judgment about others (non-customers) because of their protected characteristics. The Ashers Baking case exemplifies this second case (and here I ignore the unusual case of having 'political

\footnotetext{
${ }^{23}$ Ashers Baking (n 18) para 18.

${ }^{24}$ Bob Hepple, Equality: The New Legal Framework (Hart Publishing, 2011): pp. 55-59, 68.

${ }^{25}$ For a recent reaffirmation of indirect discrimination as a concept concerned with 'equality of results' rather than 'equality of treatment', see Essop \& Ors v. Home Office (UK Border Agency) [2017] UKSC 27.
} 
opinion' as protected characteristic). The sellers were willing to provide their services to both gay and heterosexual customers. However, they would refuse to provide their services to all customers if providing the service supported, directly or indirectly, gay marriage.

If the relevant equality law prohibits discrimination on the ground of political (or moral, ideological) opinions, as does Northern Ireland's Equality Act 2006, the relevant law in the Ashers Baking case, then both possible cases fall within its scope. If not, the inevitable question at this point would be: what is the purpose of equality laws - including the Equality Act 2010 - in their application to service providers? One possible answer would be that the purpose is to prevent service providers from discriminating against customers while relying on their protected characteristics, thus to protect customers from being discriminated against because of their protected characteristics. That would be the narrow purpose of the law. This narrow purpose is expressed in the Supreme Court's decision in Bull, where Lady Hale submitted that 'the purpose was to secure that people of homosexual orientation were treated equally with people of heterosexual orientation by those in the business of supplying goods, facilities and services'. ${ }^{26}$

A second possible answer would be that the implied purpose of equality laws is also to prevent service providers from acting upon their discriminatory views when they provide services to the general public, thus preventing service providers from refusing to provide a service if the refusal relies on an adverse judgment about others (non-customers) because of their protected characteristics. That would be the broad purpose of the law. This broad purpose was indirectly applied in Ashers Baking where the County Court in Northern Ireland decided that discrimination on the ground of sexual orientation may also exist when a service is refused because the customer 'is associated with others who are gay'. ${ }^{27}$ The court also added that 'what is required is proof of a factual matrix of less favourable treatment on the ground of sexual orientation and not the motive'. ${ }^{28}$ It is not at all clear whether this approach coincides with

\footnotetext{
${ }^{26}$ Bull para [38] $\mathrm{n}[19]$.

${ }^{27}$ Ashers Baking para [39] $\mathrm{n}$ [18]. It is not quite clear whether 'discrimination by association' is the right way to approach the facts in that case, but I will not discuss this issue here.

${ }^{28}$ Ashers Baking para [42] n [18].
} 
current law; whether current UK law on this issue is sufficiently clear; and whether this is in fact an application of the 'broad purpose' approach. This is, however, a step in the right direction. As will be argued below, the purpose of equality laws is not merely to prevent discriminatory acts from harming protected groups. Therefore, it would be wrong to only prohibit service providers from discriminating against customers because of the customers' protected characteristics. Equality laws enforce liberal moral values. They decide that certain grounds, certain differences between humans, do not justify different treatment. They prohibit service providers from acting upon their discriminatory values. Reading equality laws within this broad context must lead to an acknowledgement of their broad purpose: to prevent service providers from refusing a service to the general public if the refusal results from having discriminatory views about others - and because of these others' protected characteristics.

It is important to note that even though this broad purpose of equality laws has never been explicitly adopted by UK courts, the Equality Act 2010, much like most other equality laws, does not prevent the court from applying the broad purpose suggested here. Section 13 of the Equality Act 2010 states that 'A person (A) discriminates against another (B) if, because of a protected characteristic, A treats B less favourably than A treats or would treat others'. In the context of the facts of the Ashers Baking case, we could say that the bakery (A) discriminates against the customer (B) if, because of a protected characteristic (i.e. because of the view that gay people are not entitled to equal marriage rights), the bakery (A) treats its customers who support gay marriage (B) less favourably than they would treat others (those who do not support gay marriage). There is nothing in the language of the Equality Act 2010 that prevents this suggested interpretation.

Within the context of the cases discussed here, one may agree with the broad purpose of equality laws, and yet to argue that in these cases (and here Ashers Baking and Ladele are two relevant examples) the religious service providers did not in fact make any adverse judgment about gay people - and certainly were not homophobes. They merely subscribed to a religious perception of marriage according to which marriage is permissible only between a 
man and a woman. These religious people may support offering the option of civil partnership to gay couples. They may also see gay people as equal to heterosexuals in many other ways and support equal rights to gays in many aspects of our life - but not within the context of marriage. Accusing these religious people of making adverse judgment about gays or of being homophobes is, according to this view, misguided.

The answer to this argument is twofold. First, homophobic views, much like racist and xenophobic views, for example, can be selective or be held to various extents. One can be homophobic (or racist) with regard to certain groups or practices or within different contexts. Most people are normally not generally or absolutely homophobes or racist. When they are being homophobes or racist, it is normally within distinct contexts, and it is within these contexts that they should be identified and treated as what they are. In cases like Ashers Baking and Ladele, accusing the service providers of being homophobes or of making adverse judgment about gay people does not imply that this is who they are in all cases and under all possible circumstances. It merely accuses them of being homophobes or of making adverse judgment about gay people within the context of the right to marriage. Second, the only possible way to interpret the perception of marriage as an institution that is limited to the relationship between a man and a women (one man and one women or more) - is to see it as an institution that excludes gay couples as a result of making an adverse judgment about them. There is no other rationale - whether religious or not - for excluding gay couples from the institution of marriage, but the view that within this context gay people are not just different but also inferior and therefore have less rights than heterosexual couples. No relevant difference that is morally valid can be found between gays and heterosexuals that can explain denying gays the right to marriage. No such explanation is offered by those who object to gay marriage and do not perceive themselves as homophobes, except for repeating the unexplainable axiom that marriage, by its nature, is confined to the relationship between a man and a woman. No explanation is offered as to why this is - or has to be - the nature of marriage. 'Because God says so' is not a morally valid explanation. Tradition is also not a good enough reason as tradition alone can't provide moral justification for 
discriminatory practices. The argument that gay marriage (and indeed sex) is immoral because it is not 'of the reproductive kind' also does not survive scrutiny because there is no moral, biological or rational connection between marriage and the ability or will to have children. Agreeing to grant gay couples equal rights - except for the right to be called 'married' (thus being 'civil partners' instead, for example) is dangerously close, though not completely identical, to 'separate but equal' practices. Those who object to gay marriage are in fact making adverse judgment about gay people because of who they are - and are therefore homophobes - within the context of the right to marriage.

This point also clarifies the link between the broad purpose of equality laws - and perfectionist liberalism. In the examples above, the question that needs to be answered is whether service providers should be allowed to act on their homophobic views when they refuse to provide a service, even when the customer is not gay. Perfectionist liberalism must perceive homophobic views (or making adverse judgment about gays because they are gay) as morally repugnant. Holding these views should be allowed. Expressing them may be allowed - and that would depend on the circumstances (and here the perfectionist-liberal may take into account both contentbased considerations, i.e. the morally repugnant content of the speech, and content-neutral considerations as well). However, acting on these homophobic views, while providing services, should almost never be allowed. This is where perfectionist-liberal tolerance ends.

As to neutral liberalism, there is nothing in it that necessarily prevents service providers from denying a service even when this act relies on holding homophobic views, and especially when the customers themselves are not gay. If Neutral liberalism entails applying content-neutral considerations only, then the result of a neutralliberal approach is not predictable - as it always depends on changeable circumstances. Neutral liberalism does not require the state to take a consistent moral stand according to which equality trumps freedom of religion. In fact, it prevents the state from doing so. Neutral liberalism, therefore, can't subscribe to the broad purpose of equality laws as described above. It can't even fully subscribe to the narrow purpose, at least not as a matter of principle, because according to neutral liberalism, direct discrimination may be justified 
under certain and not at all rare circumstances, by applying the neutral considerations mentioned above.

The argument about the proper reading of equality laws as laws that prevent service providers from refusing a service to the general public if the refusal results from having discriminatory views about others - is complemented by the relation between equality laws and the harm principle.

\section{The Purpose of Equality Laws: The Harm Principle}

A common way to decide cases of conscientious objection by relying on 'content-neutral' considerations is to apply the 'harm principle' or to conduct a 'balance of harms' in order to avoid the greater harm. ${ }^{29}$ Applying such a neutral approach within the context of conscientious objection raises a clear difficulty, to the extent that the crucial criterion for granting exemptions is the amount of harm that may be caused to the conscientious objector should an exemption not be granted. The difficulty is that applying such an approach will result in granting unjustifiable exemptions to intolerant conscientious objectors. The following example can clarify this point.

Assume that the law prohibits discrimination in the workplace on the ground of race. Also assume that there are just one or two employers in a major city who refuse to employ non-whites because of religious conscientious reasons. Finally, we shall assume that, normally, there is no serious problem of racism in the workplace in that city (as opposed to many other cities in the same state) and that non-white people can easily find a job within that city. Applying a neutral test merely compares the harm that may be caused to racist conscientious objectors should an exemption not be granted and the harm that may be caused to potential employees or to the public interest should an exemption be granted. The result will have to be the granting of an exemption. This would also be the case if we do not compare the harm that may be caused to both sides but merely

\footnotetext{
${ }^{29}$ And here I interpret harm in a broad way that may include severe emotional harm, yet still distinguish it from causing offence or insult to sensitivities or feelings.
} 
try to avoid inflicting harm on the employee. ${ }^{30}$ In our case, if the jobseeker who was discriminated against found or is likely to find another job, a better job, easily and quickly, then apart from being offended by the racist employer, no meaningful harm was caused here. ${ }^{31}$ And if the job-seeker was not offended by the racist employer, because, for example, the job-seeker is not a person who is offended easily - or because she does not allow herself to be offended by racists, then in lack of harm or offence, an exemption from the equality law should be granted to the racist employer. If we wish to avoid granting exemptions to conscientious objectors who rely on a racist conscience, or on any other morally illegitimate conscience, we need to consider the content of the conscience as a reason for not granting the exemption - even when granting an exemption will not cause harm to others.

As described above, and within the context of sexual orientation, the narrow purpose of the Equality Act 2010 is to secure that people of homosexual orientation are treated equally with people of heterosexual orientation. ${ }^{32}$ Even according to this narrow perception, the purpose is not necessarily to prevent harm or to prevent violations of other rights (apart from the right to equality). The purpose is broader than that and covers either preventing offence to sensitivities - or preventing service providers from acting on discriminatory views, even when no harm or offence is caused.

The circumstances in Bull exemplify this point. In Bull no harm was caused to the gay couple. The refusal to let them the double room was not done in a demeaning manner. The gay couple found alternative accommodation at another hotel. They got their deposit back and the homophobe, yet kind owners of the B\&B even offered to 'reimburse the additional expense to which the couple had been

${ }^{30}$ C.f. Robert Wintemute, 'Accommodating Religious Beliefs: Harm, Clothing or Symbols, and Refusals to Serve Others' The Modern Law Review 77 (2014): pp. 228-229, 223. (Wintemute argues that religious objections should be accommodated if no direct or indirect harm is likely to be caused to others, even though Wintemute defines 'harm' in a fairly broad way that also includes, for example, an insult (241)).

${ }^{31}$ And here I reject, without elaborating on this point, the view that 'dignitary harm' is in fact harm rather than offence. In short, perceiving 'dignitary harm' as harm blurs the important differences between the liberal 'harm principle' and the liberal 'offence principle'. For these principles see Joel Feinberg, 'Harm to Others: The Moral Limits of the Criminal Law' (1984); Offense to Others: The Moral Limits of the Criminal Law (1985). Feinberg suggests that the offence principle deals with preventing hurt of offence (as opposed to injury or harm) to others. For perceiving 'dignitary harm' as harm see Jeremy Waldron, 'The Harm in Hate Speech' (Oliver Wendell Holmes Lectures, Harvard University Press, 2014) chapter 5 .

\footnotetext{
${ }^{32}$ Bull (n 19) para 38.
} 
put in having to find alternative accommodation, together with a modest sum for the inconvenience'. ${ }^{33}$ The only harm that was caused here found its expression in the fact that 'the refusal was very hurtful to the couple'. ${ }^{34}$ This is not part of any account of the liberal 'harm principle'. This is in fact a case of offended sensitivities. This conclusion is reinforced by the description of the remedy granted by the court: awarding 'each of the claimants $£ 1,800$ in damages for injury to feelings'.

This can lead to two possible conclusions. The first is that the Equality Act 2010 does not only protect members of vulnerable, protected groups from being harmed or from being deprived of their rights (apart from the right to equality). Rather, it also protects them from being offended by discriminatory acts. ${ }^{36}$ The second possible conclusion is that the consequences of the discriminatory act are in fact irrelevant. Thus, some discriminatory acts are inherently immoral and illegal regardless of their actual consequences in each and every specific case. That would be an implementation of perfectionist liberalism and content-based considerations - and clear rejection of neutral liberalism and content-neutral considerations: service providers are not allowed to act upon their discriminatory views - and the existence of harm or offence in a particular case is plainly irrelevant. If this conclusion is valid, it brings us back to the previous question about the purpose of equality laws: if the purpose of equality laws is broader than preventing harm or offence to - in our case - customers, and if the purpose is to prevent service providers from acting upon their discriminatory views when they provide a service to the general public, then a refusal to provide a service because the service provider holds discriminatory views about gay people, for example, is illegal regardless of whether the customer is or is not gay. Put differently, and according to a proper reading of the Equality Act 2010 and similar statutes, acting upon an intolerant, morally illegitimate conscience is illegal because of the content of the conscience and regardless of the consequences of the discriminatory act. This assertion also means that equality laws

\footnotetext{
${ }^{33}$ Ibid., para [11].

${ }^{34}$ Ibid., para [10].

35 Ibid., para [12].

${ }^{36}$ And see section 119(4) of the Equality Act 2010 (c.15): 'An award of damages may include compensation for injured feelings...'.
} 
create hierarchy of rights according to which equality decides the limits of other human rights. The very existence of equality laws means that if exercising a right (e.g. freedom of religion) results in an unjust discriminatory treatment or outcome, equality trumps the other right. In a liberal, non-religious state, the question of whether the discriminatory treatment or outcome is in fact unjust must be decided by subscribing to a liberal perception of equality - and within the framework of the relevant equality law - thus creating an inevitable hierarchy of rights.

\section{The Purpose of Equality Laws: Hierarchy of Rights}

Neutral liberals may respond to this perfectionist-liberal perception of equality laws - or equality generally - by arguing that the contentbased approach to the issue of conscientious or moral objection reflects 'monoculturalism', which denies the right to hold moral positions on certain issues that differ from the majority acceptance of them. Parkinson, for example, uses this argument in order to support the granting of an exemption from equality laws to those who refuse to take part in the registration of same-sex marriage or partnership or in conducting these ceremonies. ${ }^{37}$ Since those who refuse to take part in the registration of same-sex marriage or partnership are no different from those who refuse to sell a 'gay marriage' cake (as all refuse to provide a service because of the adverse judgment they make about gays) - the following applies to the Ashers Baking case as well.

Parkinson accuses perfectionist-liberals of 'monoculturalism' within the context of equality laws. However, it seems a bit odd to criticise equality laws for denying the right to act upon certain moral positions - as this is the exact purpose of most equality laws. It is, in fact, their nature. When equality laws include protected characteristics (in our case - sexual orientation) they take a moral view on this issue, which almost always contradicts other moral views that some people hold. The prohibition on discriminating against others on the basis of their sexual orientation is not aimed at enlightened people who would never consider discriminating against lesbian, gay, bisexual and transgender (LGBT) people, nor is it mainly aimed at

\footnotetext{
${ }^{37}$ Patrick Parkinson, 'Accommodating Religious Beliefs in a Secular Age: The Issue of Conscientious Objection in the Workplace' University of New South Wales Law Journal 34(1) (2011): pp. 281-299, 294.
} 
those who discriminate against LGBTs because of mere preferences or interests. It is aimed at homophobes and those who have moral reasons for discriminating against LGBTs. From the tolerant-liberal state's point of view, it makes no sense to exempt from equality laws the same people who are the reason for enacting such laws. It appears that the argument against 'monoculturalism' is in fact an argument against core liberal values and, perhaps not deliberately, against certain aspects of equality laws as such.

Parkinson applies pure neutral reasoning when he argues that those who refuse to obey equality laws within the context of providing services should be exempt from the law when their refusal to perform a service 'forms a very small part of the workload of the organisation and where those services could readily have been performed by many others. ${ }^{38}$ A similar view was expressed by Vickers who asked, following Ladele, if it was 'really necessary to designate all registrars as civil partnership registrars (as opposed to the clear need for all designated registrars to carry out civil partnership registrations)? ${ }^{39}$ This approach was in fact applied by some local authorities in the UK, allowing registrars with a sincerely held religious objection to the formation of civil partnerships between gay couples to opt out of designation as civil partnership registrars. ${ }^{40}$

This approach, if taken seriously, can easily justify granting an exemption to those who refuse to register marriages or partnerships - or to provide any service of any kind (educational, medical, financial, etc.) on the basis of race, religion, sexual orientation etc., as long as the discriminated group is a very small minority (generally or within the group of potential customers) - thus requiring services that form a very small part of the workload of the organisation - and as long as the service can be provided by others.

The liberal state should not hurry to compromise its liberal values - when they are expressed in value-based legislation - by applying neutral tests and granting exemptions to those who do not share these values. Such compromises will make the law - and core liberal values - redundant. It should be easier for the liberal state to apply neutral tests when it considers granting exemptions to those who,

\footnotetext{
${ }^{38}$ Parkinson (n 37) 294.

${ }^{39}$ Lucy Vickers, 'Religious Discrimination in the Workplace: An Emerging Hierarchy?' Ecclesiastical Law Journal 12(3) (2010): pp. 280-303, 294.

${ }^{40}$ Eweida v. United Kingdom (2013) 57 EHRR 213, para 25.
} 
for conscientious reasons, object to laws that do not reflect liberal values (e.g. safety laws that impose a duty to wear helmets) or to those who object to laws that contradict their conscience, yet their conscience does not reflect intolerant and anti-liberal values (e.g. an objection to performing abortions - and here I assume that perceiving the foetus as a person is not necessarily intolerant or illiberal). The liberal state does not have to grant exemptions in cases that fall within these categories, as further considerations should also be taken into account, but the fact that granting exemptions in these cases does not run against core liberal values is a reason not to refuse granting exemptions.

Equality laws, however, do not fall in either of these categories. As was rightly stated by Lord Sedley in Ladele, 'to have accommodated the requests of those Registrars seeking to avoid the conducting of civil partnerships would have resulted in (at least partially) segregated services. This is because such would necessarily result in opposite sex couples being serviced by certain Registrars and same sex couples by others. ${ }^{41}$

The European Court of Human Rights (ECtHR), while upholding the UK courts' rulings in Ladele and McFarlane, held that 'differences in treatment based on sexual orientation require particularly serious reasons by way of justification'. ${ }^{42}$ The court avoided in-depth legal analysis of these cases and openly relied on the margin of appreciation doctrine, thus allowing UK courts wide discretion when they balance between competing Convention rights. ${ }^{43}$ Yet, the above statement does reveal a content-based, liberal view according to which the principle of equality often decides the limits of freedom of religion rather than the other way around.

There are only two options here: either freedom of religion allows religious believers to discriminate against others - or equality defines the limits of freedom of religion. Between these two options, the second must be preferred, and for three reasons. ${ }^{44}$ First, equality, freedom and autonomy are the basis of all other human rights.

\footnotetext{
${ }^{41}$ Ladele (n 20) para 55.

42 Eweida (n 40) para 105.

${ }^{43}$ Eweida (n 40) para 106, 109.

${ }^{44}$ For the view that the Equality Act 2010 does create a hierarchy of rights - or that courts apply the Equality Act 2010 in a way that creates a hierarchy of rights, see Stephen Hunt, 'Negotiating Equality in the Equality Act 2010 (United Kingdom): Church-State Relations in a Post-Christian Society’ Journal of Church and State 55(4) (2012): pp. 690-711; Vickers (n 39); Sandberg (n 17) 180.
} 
Humans have rights as humans - and they are all equally human. They have rights so they could be free to be the (partial) authors of their life without fear of sanctions, being manipulated or threatened, and thus to be autonomous. Therefore the limits or the scope of all human rights, including freedom of religion, are defined inter alia by equality and freedom itself. More specifically, freedom of religion ends when it leads to an unjust discrimination against others. ${ }^{45}$ The question of whether exercising freedom of religion unjustly discriminates against others cannot be answered without subscribing to a comprehensive moral or political theory. It cannot be answered by subscribing only to neutral liberalism. It can only be answered by subscribing to either the religious point of view or to the liberalhumanist-secular point of view. If the relevant equality legislation entrenches liberal-humanist-secular values it will be inconsistent if it does not create a hierarchy of rights according to which equality sets the limits of freedom of religion. One may argue that if equality and freedom set the limits of human rights, this may result in an assertion according to which rights of others end when they unjustly violate freedom of religion. Here, again, the question of whether freedom of religion is unjustly violated cannot be answered in a satisfactory way by applying only neutral tests. This question cannot be answered without subscribing to a comprehensive moral or political theory, and here, yet again, one must choose between the religious point of view and the liberal-humanist-secular point of view. If the state and the legal system generally subscribe to a liberal point of view, prioritising religion would be possible, but inconsistent.

Second, equality must decide the limit of freedom of religion rather than the other way around, if the state already enacted an equality law - and because of the purpose of all equality laws. Enacting equality laws - and then deciding that freedom of religion decides the limits of equality, will render equality laws almost meaningless. This is so because in many liberal democracies, religious belief or conscience is one of the main motives for discriminating against certain groups - and in some cases - the dominant motive. There is, therefore, little point in enacting equality laws and then to significantly frustrate their purpose by subjecting equality to

\footnotetext{
${ }^{45}$ For a similar view, see Frances Raday, 'Culture, Religion and Gender' International Journal of Constitutional Law 1(4) (2003): pp. 663-715, 701.
} 
freedom of religion. The opposite, however, is not true. Subjecting freedom of religion to equality does not render freedom of religion meaningless. It normally does not prevent religious believers from continuing to practice their religion or act upon its values in numerous meaningful ways. And if prohibiting religious believers from unjustly discriminating against others does prevent religious believers from practicing their religion or acting upon its values in a way that significantly diminishes their overall freedom of religion, that would probably mean that from a liberal point of view, that specific religion does not prescribe a valuable way of life that is worthy of extensive legal protection. If a certain religion, or any set of beliefs, cannot be followed in a meaningful way without significantly compromising the purposes of equality legislation, and if the liberal state takes equality seriously, then that religion will either have to adjust to core liberal values - or to not enjoy the protection of the law.

Thirdly, equality must define the limits of freedom of religion rather than the other way around, because if religious beliefs trump equality, and if religious beliefs should be accorded a similar weight to any other moral belief (and maybe also philosophical or political beliefs) - and in liberal democracies that is exactly the case - then all moral beliefs would also trump equality norms and that, of course, will render equality legislation almost completely meaningless.

An interesting attempt to avoid the conclusion that within a hierarchy of rights the principle of equality trumps freedom of religion was suggested by Pitt who argues that when the courts decide that equality marks the limits of freedom of religion in cases of direct discrimination, the courts do not in fact create a hierarchy of rights. Instead, Pitt argues that insofar as there is a clash of rights, it is resolved simply by the application of the usual principles of direct and indirect discrimination, not by preferring one protected characteristic to another'. ${ }^{46}$ Therefore, preventing a religious person from directly discriminating against others is an indirect discrimination against that religious person. And here, Pitt argues, 'the distinction between direct and indirect discrimination gives effect to the underlying moral principle that less favourable treatment just be-

\footnotetext{
${ }^{46}$ Gwyneth Pitt, 'Taking Religion Seriously' Industrial Law Journal 42(4) (2013): pp. 398-408, 408
} 
cause of a protected characteristic is basically indefensible', ${ }^{47}$ whereas rules imposed for neutral reasons that have an adverse impact on people with a particular protected characteristic are capable of justification. Even according to this approach equality laws set an underlying moral principle according to which less favourable treatment just because of a protected characteristic is basically indefensible. This is indeed a moral principle that is morally contested by many, especially non-liberals. This moral-liberal principle does create a hierarchy of rights after all as it prefers the principle of equality to freedom of conscience and religion - or uses the principle of equality to decide the limits of freedom of conscience and religion.

Acknowledging that a hierarchy of rights is inevitable when we apply equality legislation (without rendering it almost meaningless) would be another reason for rejecting neutral approaches when courts decide whether to exempt conscientious objectors from the application of equality laws. In Ashers Baking the court ruled that 'where businesses are open to the public on a commercial basis, then they have to accept the public as it is constituted' ${ }^{48}$ In the Appeal the court ruled, along a similar line, that in the present case the appellants might elect not to provide a service that involves any religious or political message. What they may not do is provide a service that only reflects their own political or religious belief.... ${ }^{49}$ These rulings reflect a neutral reasoning that completely ignores the values of both the service provider and the customer. If courts follow this reasoning they will have to rule that a gay-friendly bakery, owned by gay activists, and that employ gay workers, has to provide customers cakes with icing that says, for example, 'homosexuality is a sin'. In many aspects, the statement 'homosexuality is a sin' is not different from 'support gay marriage'. Both statements are legal; both contradict deeply held beliefs of others; and both reflect deeply held beliefs - religious or others. And yet, treating these statements or cases the same will run against core liberal values - and the purpose of equality legislation. Within the commercial context, the purpose of equality laws is or should be to prevent service providers from acting upon their discriminatory values. Forcing homophobe service providers to act against their discriminatory values - or

\footnotetext{
${ }^{47}$ Pitt (n 46) 408.

${ }^{48}$ Ashers Baking (n 18) para 32.

${ }^{49}$ Gareth Lee v. MacArthur [2016] NICA 39, para 100.
} 
preventing them from acting upon these values, coincides with perfectionist liberalism and the purpose of equality laws. Forcing gay service providers to enable customers to act upon their discriminatory values or to convey their discriminatory values (e.g. by printing discriminatory messages for them) runs against perfectionist liberalism and the purpose of equality laws. If equality defines the limits of freedom of religion - or freedom of expression (including the right not to manifest views to which one objects), then service providers should not be forced to assist a customer to convey a certain message only if (a) the message contradicts the service provider's deeply held belief, or diminishes important aspects of the service provider's identity or way of life; and (b) the refusal to convey the message does not rely on discriminatory, unjustly intolerant or morally repugnant values - or results from such values. Genuine liberalism does not countenance an 'either/or' here; the former condition only has meaning within a liberal framework if the latter condition is also met.

Within the framework of perfectionist liberalism and equality laws, this is where the difference between the above two statements lies. 'Support gay marriage' does contradict deeply held beliefs of some religious people but it does not convey discriminatory values and does not result from such values. It does not perceive religious people as less worthy as humans or right-holders because of who they are. It does not contradict core values of liberalism - the same values that stand at the heart of all meaningful equality laws. The refusal to convey the message does rely on discriminatory, unjustly intolerant and morally repugnant values and therefore should not be protected by the law. 'Homosexuality is a sin', however, does not just contradict deeply held beliefs of some people. It conveys discriminatory values and results from such values. These are the same values that equality laws themselves perceives as illegitimate. It perceives gay people as less worthy as human-beings or right-holders because of who they are. Forcing service providers to actively enable conveying these views or to assist in conveying them - while relying on equality or anti-discrimination legislation - is self-contradictory. Having hierarchy of rights means that at least within the context of equality laws (a) religious belief cannot justify treating others less favourably; and (b) religious belief - as far as it is conveyed by 
expressing discriminatory views - may, under certain and exceptional circumstances (that were described above), form a reason to treat the one who holds that belief less favourably, for example by denying a service.

\section{E. The Orwellian Argument: Equality Laws as Discriminatory Laws}

A common argument made either explicitly or implicitly by many is that the court should at least appreciate that those who are prevented from discriminating against others, even though their conscience or religion prescribes such discrimination, are or may be the ones who are being discriminated against. ${ }^{50}$ That was in fact the argument presented by the Attorney General in Ashers Baking before the Court of Appeal. The Attorney General argued that requiring the bakery's owners to produce a political message with theological content to which they objected on the grounds of their own religious belief (and political opinion) 'constituted less favourable treatment of them in comparison with the persons sharing the political and religious views expressed in the message. ${ }^{51}$

Two different tests can be applied here in order to refute this argument. The first is the intention/motive test, which is a neutral one. This test asks who was the first who restricted (in the broadest sense possible) the freedom of others - or discriminated against others - because of a negative opinion about these others or their values. The second is a content-based test that gives priority to liberal values over non-liberal ones.

If we apply the intention/motive test to the Ashers Baking case, we will find that the buyer did not aim to discriminate against religiousChristian cake sellers because of their religion or religious belief. He did not treat them differently because of their religious belief or indeed at all. His initial purpose was not to limit their freedom of religion because he made an adverse judgment about their identity or their values. The sellers, however, did exactly that. They refused to serve a customer because of the adverse judgment they made

\footnotetext{
${ }^{50}$ For this argument, see Julie Maher, 'Eweida and Others: A New Era for Article 9?' International \& Comparative Law Quarterly (2014): pp. 231-232, 213; Russell Sandberg, 'Laws and Religion: Unravelling McFarlane v. Relate Avon Limited’ Ecclesiastical Law Journal 12(3) (2010): pp. 361-370, 363; Julie Rivers, 'The Secularisation of the British Constitution' Ecclesiastical Law Journal 14(3) (2012): pp. 371-399, 383.

${ }^{51}$ Ashers Baking 2016 (n 49) para 91.
} 
about gay people as such - and as a result - about the customer's views.

Ignoring the intention/motive test may lead to Orwellian assertions. The 'pro-religious', 'anti-gay' joint dissenting opinion of judges Vucinic and De Gaetano in the Eweida case exemplifies this point. The ECtHR judges argued that Ladele, who refused to register civil partnerships between gay couples, was in fact the one who was discriminated against. This was so because 'given the cogency, seriousness, cohesion and importance of her conscientious objection ... it was incumbent upon the local authority to treat her differently from those registrars who had no conscientious objection to officiating at same-sex unions, ${ }^{52}$ Ignoring the intention/motive test allowed the judges to argue that those who discriminate against others are in fact being discriminated against precisely because the law prohibits them to discriminate against others. Thus, anti-discrimination laws in fact discriminate against those whose conscience compels them to discriminate against others. George Orwell must be laughing in his grave.

The intention/motive test cannot be a sufficient or conclusive one, precisely because of its neutral nature. It has to be complemented by a content-based test that gives priority to liberal values over non-liberal ones. Northern Ireland's Equality Act 2006, for example, in the light of which the Ashers Baking case was decided, best explains the need for this complement. The Act prohibits discrimination on the ground of political opinion. Let us assume, again, that a bakery is owned by a group of gay activists and is known as a 'gay-friendly' bakery. A customer orders a cake with the print 'say no to same-sex marriage' or 'homosexuality is a sin'. Both expressions are legal, thus according to the court's reasoning in the Ashers Baking case (the Court of Appeal), the sellers will have to bake and sell such a cake. ${ }^{53}$ Therefore, a 'gay-owned/friendly bakery' will have to indirectly support anti-gay and homophobic statements in the same way a Christian-owned bakery has to sell a pro-same-sex marriage cake.

\footnotetext{
${ }^{52}$ Eweida (n 40) dissenting para 7. See also, Ryan Hill, 'Non-discrimination on Grounds of Sexual Orientation: Should the Law Accord Exemptions on the Basis of Freedom of Conscience?' Questions of International Law 7 (2014): pp. 13-26, 19: ('failing to allow a religious person to follow the dictates of their \{discriminatory\} conscience may in itself be discriminatory').

${ }^{53}$ For the 'legality of the expression' test, see Ashers Baking (n 18) para 62.
} 
This symmetry between pro-gay and anti-gay statements is morally wrong. It results from not taking a moral stand for or against anti-gay expressions and homophobic views. The symmetry is wrong because there is nothing in homosexuality as such - or in the demand for equal rights to gay people - that intends to deny the legitimacy of others, to condemn their way of life or to exclude it legally, socially, culturally or physically. Homosexuality, as such, does not entail making adverse judgments about others. However, the very essence of religious or conservative homophobia, when it is expressed openly or being used as reasons for action, is making an adverse judgment about homosexuals as such, condemning homosexuality as immoral or excluding it legally, culturally or even physically. A liberal state that refuses to take a moral stand against homophobia ceases to be a liberal state. It will only be a neutral state, denying its duty to protect people from acts that are committed on the ground of seeing other human beings as less worthy.

This is not to say that all private employers who have deeply held moral values should be allowed to discriminate against those who think differently. This will only be the case when the employer or the service provider deeply holds liberal values - that the law itself entrenches - and when the employee or job-seeker holds anti-liberal, intolerant and morally repugnant values, or when a client or a buyer asks for a service that compels the service provider to identify with these repugnant values or to help promoting them. Presumably, this will only rarely be the case, but as the Ashers Baking case demonstrates, rare cases are only rare, not hypothetical.

The neutral intention/motive test according to which we ask who was the first who treated others differently merely shifts the burden of proof. It is for those who were the first to discriminate against others to justify their acts. Such justification may be found if the discriminator acts upon liberal values - and as a reaction to an act or a demand which is based on anti-liberal, morally repugnant values.

The purpose of equality acts is to prevent discrimination based on protected grounds. Confusingly, one of these protected grounds is religion. This is confusing because religious belief is quite often the reason for a discriminatory approach against others. Moreover, 
religious belief is presumably the only protected ground that can itself be a reason for discriminating against others. ${ }^{54}$

But religious belief is merely a belief. Unless it is argued that religious belief should be singled out for special, positive treatment and that would be incompatible with any meaningful version of liberalism and with the principle of equality itself - equality laws should be interpreted in the following way: discriminating against religious people only because they are religious, while completely ignoring the content of their religious belief or the general content of their religion - is morally wrong and also illegal. At the same time, religious belief should almost never form a legal reason for discriminating against others unless we are willing to allow all those who are morally committed to discriminatory views to act upon these views and to discriminate against others. And that would obviously be a death sentence for all equality laws. This explains why arguing that preventing people from discriminating against others, even though their conscience or religion prescribes such discriminating, is in fact discrimination - is an Orwellian argument. Such an argument empties equality laws of their content and purpose and leads to a legal permission to discriminate merely because one deeply holds discriminatory values.

The Court of Appeal in Ashers Baking, that applied a neutral approach throughout its ruling, indicated that it would be ironic if the constitutional protections against legislative or executive discrimination based on religious belief or political opinion... were to become the instruments for the support of differential treatment of fellow citizens based on religious belief and political opinion'. ${ }^{55}$ The reluctance to accept the Orwellian argument is just, yet accepting the Orwellian argument will be a bit more than ironic. It would be paradoxical - and in terms of achieving the purpose of equality legislation - self-defeating.

Another pro-religion Orwellian argument is that in recent UK case-law the courts created a 'hierarchy of equalities' in which religious equality takes a subordinate position. Using the term 'religious equality' to describe the religious person's alleged right not be discriminated against when they discriminate against others is Orwel-

\footnotetext{
${ }^{54}$ Aileen McColgan, Discrimination, Equality and the Law (Hart Publishing, 2014): p. 136.

55 Ashers Baking 2016 (n 49) para 101.
} 
lian and misleading. 'Religious equality' cannot include the right to discriminate against others. As argued above, all that 'religious equality' can include in a tolerant-liberal democracy that does not favour racist, homophobic or sexist religious beliefs over identical beliefs that are non-religious, is the right not to be discriminated against merely because one is religious (regardless of the content of one's religious beliefs - or the content of one's religion). It does not follow that religion should be treated in like fashion to ethnicity or sexual orientation for the purposes of equality laws. ${ }^{56}$ It does mean that 'religion' should be distinguished from 'religious belief for the purposes of equality laws, as the former is closer to one's identity or status than the latter. This distinction between identity and belief is important - and the subject of the next section.

\section{F. Discrimination on the Ground of Identity and Discrimination on the Ground of Belief $f^{5}$}

Earlier I argued that the purpose of equality laws is to prevent service providers from acting upon their discriminatory views when they provide services to the general public, thus preventing service providers from refusing to provide a service if the refusal relies on an adverse judgment about others (non-customers) because of their protected characteristics. I argued that this is the broad purpose of equality laws - including the Equality Act 2010.

The broad purpose of the law may be rejected by anti-liberals and neutral liberals alike. A 'pluralist', 'multi-culturalist', neutral position led some liberals to protect the right of the sellers in Ashers Baking to refuse to sell a 'gay marriage' cake. Their reasoning, within the special context of Ashers Baking, goes as follows: service providers should be allowed to act upon their values and thus to refuse to provide their services as long as the refusal does not rely on the customer's protected characteristics but on the customer's views. ${ }^{58}$ This is so even when the customer's views, or more accurately the message that the customer wishes to convey, are within the boundaries of the law. This is a neutral position as it allows all

\footnotetext{
${ }^{56}$ As was rightly suggested by McColgan (n 54) 169, 171.

57 The concepts 'identity' and 'belief are complex and the relation between identity and belief raises complex questions. I will refrain from discussing these concepts and questions here.

58 This view was taken by the UK Supreme Court in Ashers Baking: (n 18) paragraph 52.
} 
service providers to refuse to provide their services on that ground and regardless of the moral soundness or legitimacy of their own values.

Therefore, and to take a few examples which were suggested by Spenser, a Catholic bakery should be allowed to refuse to sell a cake with a pro-abortion icing; a Muslim-owned bakery should be allowed to refuse to sell a cake proclaiming 'Jesus is our Lord'; a secular owned bakery should be allowed to refuse to sell a cake calling for Sharia law; and a Christian-owned bakery should be allowed to refuse to sell a 'gay marriage' cake. ${ }^{59}$ These examples are misleading because there is a crucial difference between the first three examples and the Ashers Baking case. Opposing abortions, Christianity or Sharia law may or may not be morally sound but it should be tolerated by equality laws - and the law generally. A refusal to support, directly or indirectly, a world view that contradicts one's deepest moral beliefs should normally be tolerated by the law. However, opposing gay marriage is not quite the same as opposing abortions, Christianity or Sharia law. The latter three are about views, ideologies and beliefs. Opposing other people's views should be tolerated or respected - and in any event allowed. The former, however, (opposing gay marriage) is about people's identity. It is about perceiving other people as non-equal because of who they are. People may hold these views but acting upon such views should normally not be allowed.

Therefore, it is misleading to compare the Ashers Baking case to cases where service providers refuse to support views of any kind that contradict their deepest moral beliefs. The right comparison in this case is a refusal to sell a cake calling for or supporting inter-racial marriage. If a racist-white-owned bakery refuses to sell a cake to a white customer because the cake calls for inter-racial marriage, how would neutral liberals react? If they prohibit such a refusal they will have to substitute their neutrality with a more desirable, perfectionist version of liberalism. They will actually have to take a moral stand against certain values because of their content. If, however, they allow such a refusal, it will demonstrate the moral shortfall of neutral liberalism.

\footnotetext{
59 Nick Spenser, 'Storm in a Gay Cake Tin', Think Tank (Feb. 3, 2016), http:/ /www.theosthinktank. co.uk/comment/2016/02/03/storm-in-a-gay-cake-tin\#sthash.GBg40dBK.dpuf (accessed 3rd February 2016).
} 
If a racist-white-owned bakery refuses to sell a cake to a white customer because the cake calls for inter-racial marriage, what would be the legal response according to the Equality Act 2010, which does not prohibit discrimination on the ground of political opinions? The only possible way to compel the bakery to sell such a cake would be to adopt the broad purpose of equality laws, which is to prevent service providers from acting upon their discriminatory views when they provide services to the general public, regardless of the identity of the customer.

The comparison to racial discrimination is not coincidental. In Ladele Lord Sedley rightly suggested that exempting homophobic registrars from equality laws, thus allowing them not to provide services to same-sex couples would be as repugnant as racial segregation that is now almost unanimously perceived as morally illegitimate. $^{60}$

Northern Ireland's Equality Act 2006 (because it includes 'political opinion' as a ground of discrimination), the Equality Act 2010 (because it includes religious belief as a ground of discrimination) and also Article 9 of the European Convention on Human Rights (ECHR) raise a broad issue, which will not be discussed in full here, pertaining to the difference between identity and ideology or belief. Discriminating against persons - or not tolerating persons merely because of their identity (e.g. their race, colour, ethnic origins, sexual orientation, etc.) is almost always morally wrong. However, discriminating against persons - or not tolerating persons because of their views, ideologies or beliefs - including religious ones - may be morally wrong but the presumption of immorality that is followed by a presumption of illegality is much weaker here. ${ }^{61}$ This has nothing to do with the question of which grounds may or may not be relevant to a person's ability to undertake work, ${ }^{62}$ nor with the ability to choose, as neither identity nor deeply held moral beliefs are chosen (and I do not intend to elaborate on this point here). ${ }^{63}$ The

\footnotetext{
${ }^{60}$ Ladele (n 20) para 48.

${ }^{61}$ For a discussion in the still underdeveloped question of whether one has a right to discriminate against others because of their non-religious beliefs, see McColgan (n 54) 159-165.

${ }^{62}$ C.f. Mark Bell and Lisa Waddington, 'Reflecting on Inequalities in European Equality Law' European Law Review 28(3) (2003): pp. 349-369.

${ }^{63}$ For the 'lack of choice' argument with relation to moral and conscientious beliefs, see Yossi Nehushtan and John Danaher, 'The Foundations of Conscientious Objection: Against Freedom and Autonomy’ Jurisprudence 9(3) (2018): pp. 541-565.
} 
distinction between people's identity and people's views lies elsewhere.

All humans are equal as humans. As such, they should be treated equally (subject to rare exceptions) regardless of their identity i.e. regardless of their human characteristics (their race, colour, ethnic origins, sexual orientation, etc.) or, perhaps, status. ${ }^{64}$ While all humans are worthy of equal respect as humans, at least as a starting point, not all views, ideologies or beliefs - including religious ones are worthy of equal respect. Some views are morally sound and worthy of respect. Others are misguided yet should still be tolerated - and may also not form a valid reason for different treatment (at least under certain circumstances or within certain contexts). But there are views that are morally illegitimate and as such should not be tolerated in a liberal democracy. These views would normally form a valid reason for a proportionate different treatment. Discriminatory views, those that entail adverse judgments about others because of who they are, are an example of such views.

The distinction between identity and views, including religious views, is reinforced by the link between equality and dignity. Human dignity is the foundation of most human rights and certainly one of the most fundamental foundations of the principle of equality. ${ }^{65}$ 'Human dignity' may have various meanings. According to the common perception of the concept, discrimination on the ground of a person's identity is more likely to harm their dignity and at times to humiliate them than discrimination on the ground of their views. ${ }^{66}$

It is a truism that respecting or merely tolerating all political, ideological, conscientious and religious views is practically impossible and in any event undesirable. Such moral relativism is not, has not and cannot be applied by any state. Respecting all humans as humans, however, is certainly possible and, subject to rare exceptions, desirable.

Sexual orientation is part of one's identity rather than one's views or beliefs. As such, it is no different from one's race or ethnic origins (and I do not imply that there are no other differences between sexual identity, race and ethnic origins). All form part of a person's

\footnotetext{
${ }^{64}$ McColgan (n 54) 60-63.

${ }^{65}$ McColgan (n 54) 23-32; Hepple (n 24) 14-16.

${ }^{66}$ McColgan (n 54) 170. In lack of a better word I use the term 'harm' with regard to dignity, even though this 'harm' falls outside the scope of the liberal 'harm principle'.
} 
identity, all are in-born characteristics and all are often grounds for discrimination and persecution. ${ }^{67}$ Nowadays not tolerating racial discrimination is part of a very wide consensus. It is indeed safe to assume that the ECtHR would not be willing to accept an argument that Article 9 protects a racist religion or a manifestation of such a religion. ${ }^{68}$ But on what grounds can we differentiate between racism and homophobia within the context of equality laws?

Many who would object to religious racism preach for tolerating religious homophobia. Rex Ahdar, for example, argues that as a starting point 'no-one ought to be forced to marry a couple against that person's religious beliefs or conscience'. ${ }^{69}$ This starting point is far from being obvious as most conscientious reasons for refusing to marry a couple rely on suspect classifications such as sexual identity and race. More importantly, Ahdar then refers to Bruce MacDougall's criticism on the common legal or social practice of accommodating objections to conducting same-sex marriage ceremonies. MacDougall's argues that 'to only allow refusals to conduct SSM [same-sex marriage] (and not refusals to marry, say, opposite-race or divorced couples) demonstrates that the state is not trying to accommodate religious consciences in general but rather it is "simply supportive of religious hostility to homosexuals, ie, homophobia" "70 Ahdar's response is that this criticism is misplaced because 'the granting of an exemption for devout commissioners does not demonstrate that the state necessarily accepts the views of those commissioners'. ${ }^{71}$ It is true that exempting either religious officials or state's officials from equality laws - and only with regard to same-sex marriage - does not imply that the state itself holds or positively

${ }^{67}$ For a persuasive argument that the state should not grant tax benefits to institutions that discriminate on the basis of sex (rather than just on the basis of race) even if the discriminatory practice is based on religious grounds, see Caroline Corbin, 'Expanding the Bob Jones Compromise' in Austin Sarat (ed.), Legal Responses to Religious Practices in the United States: Accommodation and its Limits (2012) 123. For a similar view regarding the denial of state funds to institutions that discriminate, see another article from the above collection: Corey Brettschneider, 'How Should Liberal Democracies Respond to Faith Based Groups that Advocate Discrimination? State Funding and Non-Profit Status', ibid. 72. There is no principled argument preventing expanding these views to discrimination on the basis of sexual identity.

${ }^{68}$ Christopher McCrudden, 'Multiculturalism, Freedom of Religion, Equality, and the British Constitution: The JFS Case Considered' International Journal of Constitutional Law 9(1) (2011): pp. 200229, 224.

${ }^{69}$ Rex Ahdar, 'Solemnisation of Same-Sex Marriage and Religious Freedom' Ecclesiastical Law Journal 6(3) (2014): pp. 283-305.

${ }^{70}$ Bruce MacDougall, 'Refusing to Officiate at Same-Sex Civil Marriages', Saskatchewan Law Review 69 (2006): pp. 351-374, 358.

${ }^{71}$ Ahdar (n 69) 296. 
promotes homophobia. But Ahdar is too quick to dismiss the race sexual orientation comparison, because when the state allows refusals to conduct same-sex marriage but not refusals to conduct interracial marriage, the state expresses a moral view according to which racism should not be tolerated, even when it is based on conscientious-religious reasons, whereas homophobia should. This is a powerful statement. Even if it should not be interpreted as direct state support of religious homophobia it certainly classifies homophobia as tolerable, at least to a certain extent. It also classifies homophobia as acceptable, certainly from the legal point view.

The liberal state - if it is indeed liberal - should not be sluggish when it walks the path of treating homophobia as it treats racism. A reluctance to tolerate homophobic claims for exemptions from equality laws would be a good start.

\section{TWO CONCLUSIONS}

The conclusions that can be drawn from the above are of two kinds: general ones and more specific ones. The general conclusions relate to equality laws within the context of providing services to the general public - and to equality laws more generally. The more specific conclusions relate to the case of discriminating against gay people - within the context of providing services to the general public.

I argued that if accommodating conscientious objections is almost always an expression of tolerance, then deciding whether to accommodate conscientious objections means deciding the limits of tolerance. By enacting equality laws the liberal state decides the limits of liberal tolerance by relying on content-based rather than content-neutral considerations. More specifically, equality laws' broad purpose, within the context of providing services, should be read as preventing service providers from acting upon their discriminatory views when they provide services to the general public, thus preventing service providers from refusing to provide a service if the refusal relies on an adverse judgment about either customers or non-customers because of their protected characteristics.

Equality laws do not only reflect the liberal harm principle or the offence principle. Their purpose is not only to prevent inflicting harm or offence but also to prevent service providers from acting 
upon their discriminatory views, regardless of the existence of harm or offence in a particular case. Equality laws also create a clear hierarchy of rights according to which equality decides the limits of freedom of religion. Finally, equality laws and their judicial application should - and to a certain extent do - perceive discrimination on the basis of a person's identity as more suspicious than discrimination on the basis of a person's belief, including religious belief.

Equality laws therefore are not and cannot be neutral. They reflect a content-based moral decision about the importance and weight of the principle of equality vis-à-vis other rights or interests. This leads to the following conclusions.

First, since equality laws in liberal democracies reflect moralliberal values, conscientious objections to equality laws rely, almost by definition, on unjustly intolerant, anti-liberal and morally repugnant values. If the liberal state takes its liberal and morally desirable equality laws seriously, it should not rush to compromise its liberal values by exempting conscientious objectors from the application of these laws.

Secondly, since equality laws in liberal democracies reflect a moral-liberal point of view, we should not shy away from explicitly relying on these views when we decide if it is justifiable to exempt conscientious objectors from the application of these laws. Accordingly, we should avoid applying content-neutral considerations as conclusive considerations when answering this question. Moral consistency should lead us to conclude that conscientious objections to equality laws should not be tolerated and accommodated by granting exemptions as judicial remedy because such objections rely on unjustly intolerant, anti-liberal and morally repugnant values that should not be tolerated by a tolerant-liberal democracy.

As to the more specific conclusions, those that relate to the case of discriminating against gay people - within the context of providing services to the general public: the non-compromising approach that is suggested in this paper prevents people who hold discriminatory views about gay people from acting on these views in almost all cases. This fairly radical perfectionist-liberal approach results in harsh consequences with regard to people who may be described as 'otherwise moral' and ways of life that may be described 
as 'otherwise worthy'. ${ }^{72}$ This is a valid concern. People who are generally moral, who live generally worthy life, may hold homophobic views within the narrow context of gay marriage only. It may be tempting to exempt these people from the application of equality laws - within this narrow context only, subject to further conditions (the existence of alternative service providers, for example). This temptation should be resisted. If the objection to gay marriage forms a tiny part of a person's otherwise morally good character and worthy life, then the harm that is caused to that person's moral personhood as a result of compelling them to refrain from acting on their discriminatory values - is minimal. This harm is outweighed by the pressing moral and social need to convey a message that acting on discriminatory values will not be tolerated by the law. It is outweighed by the moral and social need to prevent discriminatory practices to form a legitimate part of the public sphere.

But what if the objection to gay marriage forms a significant part of one's character, values and way of life? In that case, the harm caused to one's moral personhood as a result of preventing them from acting on their discriminatory values - will also be significant. However, if the objection to gay marriage forms a significant part of one's character, values and way of life - then that character is no longer morally good and that way of life is no longer valuable. These are the people and ways of life which are the reasons for enacting equality laws. Tolerating them by granting exemptions from equality laws will defeat the purpose of these laws.

Last concern within the context of objecting to equality laws because one objects to gay marriage - is that gay or same-sex marriage is a relatively new institution - and that social and moral norms do not always change for the better as fast as we would like them to. The law should, perhaps, be quicker when it comes to allowing gay marriage, and a bit slower when it comes to enforcing anti-discrimination laws within this context, at least in some typical cases. This concern gives rise to difficult questions about the purpose of law, the ability of the law to lead social changes, and the costs of perfectionist-liberal intolerance. These questions will not be discussed here. The perfectionist-liberal approach that was applied here may allow exceptions - in extremely rare cases. It may allow

\footnotetext{
72 And I thank the anonymous reviewer for raising this legitimate concern - and the other concern that follows.
} 
homophobes to act on their homophobic views in the most exceptional cases - that will not be discussed here. The general approach, though, remains intact: in a tolerant-liberal democracy, conscientious objections to equality laws should not be tolerated and accommodated by granting exemptions from these laws.

\section{OPEN ACCESS}

This article is distributed under the terms of the Creative Commons Attribution 4.0 International License (http:// creativecommons.org/licenses/ by $/ 4.0 /$ ), which permits unrestricted use, distribution, and reproduction in any medium, provided you give appropriate credit to the original author(s) and the source, provide a link to the Creative Commons license, and indicate if changes were made.

\footnotetext{
School of Law

Keele University, Keele, ST5 5BG, UK

E-mail:y.nehushtan@keele.ac.uk
}

Publisher's Note Springer Nature remains neutral with regard to jurisdictional claims in published maps and institutional affiliations. 